123 | Anis Rugaiyah, Rivai Bolotio, Ardianto

ISSN 2528-0295 (print)/ISSN 2528-0309 (online)

Journal of Islamic Education Policy

2017, Vol.2, No.2, 123-139

Diterbitkan Online Desember 2017 (http://journal.iain-manado.ac.id/index.php/jiep)

\title{
Pengaruh Motivasi Belajar dan Kegiatan Ekstrakurikuler Sanggar Alquran terhadap Prestasi Belajar Siswa pada Mata Pelajaran Alquran Hadis di Madrasah Aliyah di Kota Manado
}

\author{
Anis Rugaiyah \\ Madrasah Aliyah Negeri Model 1 Manado, Sulawesi Utara \\ Email: anisrugaya@yahoo.co.id.
}

\section{Rivai Bolotio}

Program Pascasarjana, Institut Agama Islam Negeri (IAIN) Manado, Sulawesi Utara Email: rivaibolotio@iain-manado.ac.id

\author{
Ardianto \\ Program Pascasarjana, Institut Agama Islam Negeri (IAIN) Manado, Sulawesi Utara \\ Email: ardianto@iain-manado.ac.id
}

\begin{abstract}
This study aims to analyze the influence of learning motivation and extracurricular activities of the Quran studio either partially or simultaneously to the students' learning achievement on the subjects of Alquran Hadith at Madrasah Aliyah in Manado City. The population in this study are all 300 students of Madrasah Aliyah in Manado City in School Year of 2016/2017 who have been participating in the extracurricular activities of Alquran studio. To determine the sample of this research, the researcher uses a table which was developed from the formula of Isaac and Michael. According to the table, for a population of 380 people, the sample size needed is 161 people with 5\% error rate. The data are collected using the questionnaire. Construct and content validity analysis are performed applying Pearson correlation, using SPSS for Windows. To test the reliability of the questionnaire, Alpha-Cronbach is run. Research hypothesis testing conducted with multiple regression at the real level of 0.05 . The regression test is conducted, using SPSS for Windows. It can generally be concluded that (1) there is a significant influence of student's learning motivation on student achievement of Madrasah Aliyah in Manado City inAlquran Hadith subject, (2) there was significant influence of extracurricular activities of Alquranstudio to the students achievement of Madrasah Aliyah in Manado City in Alquran Hadith subject, and 3) there was significant influence of students' learning motivation and extracurricular activities of Alquran studio simultaneously on the students learning achievement of Madrasah Aliyah in Manado City in the subject of Alquran Hadith.
\end{abstract}

Keywords: Learning motivation, extracurricular, Quran studio, learning achievement

ABSTRAK Penelitian ini bertujuan untuk menganalisis pengaruh motivasi belajar dan kegiatan ekstrakurikuler sanggar Alquran baik secara sendiri-sendiri (parsial) maupun secara bersamasama (simultan) terhadap prestasi belajar siswa pada mata pelajaran Alquran Hadis di Madrasah Aliyah Kota Manado.Populasi dalam penelitian ini adalah seluruh siswa Madrasah Aliyah yang ada di Kota Manado Tahun Pelajaran 2016/2017 yang mengikuti kegiatan ekstrakurikuler sanggar Alquran, yang berjumlah 300 siswa. Untuk menentukan sampel penelitian, peneliti 
menggunakan tabel yang dikembangkan dari rumus Isaac dan Michael, di mana berdasarkan tabel tersebut untuk populasi yang berjumlah 300 orang maka sampelnya berjumlah 161 orang dengan taraf kesalahan 5\%. Data penelitian dikumpulkan dengan menggunakan teknik angket. Pengujian validitas angket dilihat dari segi validitas konstruk dan validitas isi melalui pertimbangan ahli dan validitas isi melalui analisis korelasi Pearson dengan menggunakan program SPSS for Windows 23. Untuk pengujian reliabilitas angket dilakukan dengan analisis alphacronbach. Pengujian hipotesis penelitian dilakukan dengan Regresi Ganda, pada taraf nyata 0,05. Proses penghitungan pengujian regresi menggunakan program SPSS for Windows 23. Hasil penelitian ini secara umum dapat disimpulkan: (1) terdapat pengaruh yang signifikan motivasi belajar siswa terhadap prestasi belajar siswa Madrasah Aliyah di Kota Manado pada mata pelajaran Alquran Hadis, (2) terdapat pengaruh yang signifikan kegiatan ekstrakurikuler sanggar Alquran terhadap prestasi belajar siswa Madrasah Aliyah di Kota Manado pada mata pelajaran Alquran Hadis, dan (3) terdapat pengaruh yang signifikan motivasi belajar siswa dan kegiatan ekstrakurikuler sanggar Alquran secara bersama-sama terhadap prestasi belajar siswa Madrasah Aliyah di Kota Manado dalam mata pelajaran Alquran Hadis.

Kata kunci: Motivasi belajar, ekstrakurikuler, sanggar Alquran, prestasi belajar 


\section{Pendahuluan}

Pendidikan merupakan kegiatan yang dilakukan dengan sengaja agar siswa memiliki sikap dan kepribadian yang baik, sehingga penerapan pendidikan harus diselenggarakan sesuai dengan Sistem Pendidikan Nasional berdasarkan UU No. 20 tahun 2003. Menurut UU tersebut, jenis dari pendidikan menengah salah satunya adalah Madrasah Aliyah (MA). Madrasah Aliyah merupakan sekolah menengah setingkat SMA yang berada di bawah naungan Kementerian Agama. Sekolah yang baik tentunya mampu menciptakan sumber daya manusia yang berkualitas dan berprestasi. Terkait dengan dunia pendidikan, untuk menciptakan manusia yang berkualitas dan berprestasi tinggi maka siswa harus memiliki prestasi belajar yang baik. Prestasi belajar merupakan hasil yang telah dicapai siswa setelah melakukan kegiatan belajar selama waktu yang telah ditentukan bersama.

Untuk dapat mencapai prestasi yang baik siswa haruslah memiliki motivasi belajar yang tinggi, karena dalam motivasi belajar terkandung adanya cita-cita atau aspirasi, ini diharapkan siswa mendapat motivasi belajar sehingga mengerti apa yang menjadi tujuan dalam belajar.

Motivasi belajar yang dimiliki oleh siswa dalam setiap kegiatan pembelajaran sangat berperan untuk meningkatkan prestasi belajar siswa dalam mata pelajaran tertentu (Nashar, 2004, p. 11). Siswa yang bermotivasi tinggi dalam belajar memungkinkan akan memperoleh prestasi belajar yang lebih tinggi pula. Artinya semakin tinggi motivasinya, semakin tinggi intensitas usaha dan upaya yang dilakukan, maka semakin tinggi prestasi belajar yang diperolehnya.

Konsep pendidikan formal di sekolah dibagi atas intrakurikuler dan ekstrakurikuler. Kegiatan intrakurikuler adalah kegiatan yang dilakukan oleh sekolah yang sudah teratur, jelas, dan terjadwal dengan sistematik. Kegiatan ekstrakurikuler biasanya dilakukan siswa di luar jam mata pelajaran. Kegiatan ekstrakurikuler bertujuan untuk menggali bakat dan memotivasi siswa dalam bidang tertentu. Karena itu, aktivitas ekstrakurikuler itu harus disesuaikan dengan keinginan serta kondisi siswa sehingga melalui kegiatan tersebut, siswa dapat memperjelas identitas diri. Banyak macam ekstrakurikuler yang ada di sekolah, misalnya: Palang Merah Remaja (PMR), Pramuka, olahraga, Sispala, Paskibraka dan juga ekstrakurikuler di bidang keagamaan yang berupa sanggar Alquran.

Pendidikan dengan aksara dan jiwa Alquran, antara lain berupa pemahaman, peng-hayatan, dan pengamalan Alquran serta kajian-kajian Islam. Pendidikan tersebut dapat menjadikan anakanak umat Islam menjadi generasi idaman dan harapan di masa depan, dan mampu merealisasikan pengamalan Alquran dalam kehidupan bermasyarakat terutama dalam hal keimanan dan ketakwaan kepada Allah Swt., serta berakhlak mulia. Allah Swt., telah menjanjikan akan mengangkat harkat dan martabat generasi yang terus menerus membumikan Alquran.

Peningkatan prestasi seorang anak dalam belajar bukan hanya ditentukan oleh ke-seriusan seorang siswa dalam belajar, melainkan salah satunya bisa dengan mengikuti kegiatan ekstrakuriker. Kegiatan ekstrakurikuler merupakan suatu sarana pendukung dalam peningkatan prestasi belajar siswa, karena di dalamnya memuat segala cara yang dapat menciptakan kreativitas khususnya dalam aspek agama, yang nantinya daya kreativitas itu dapat mendukung daya pikir anak.

Sebagai suatu kegiatan ekstrakurikuler, sanggar Alquran mempunyai suatu strategi dan pendekatan pembinaan yang bukan hanya semata-mata pengajaran saja, melainkan juga pendidikan atau pembinaan agama. Hal ini lebih diarahkan dalam membentuk dan membina siswa untuk menjadi muslim yang sejati dan benar-benar menghayati nilai-nilai agama dan mengindahkan norma-norma agama dalam kehidupan sehari-hari.

Terdapat beberapa penelitian sebelumnya yang juga membahas mengenai pengaruh motivasi belajar dan kegiatan ekstrakurikuler dengan prestasi belajar siswa. Di antaranya penelitian Yusni 
Harahap (2015, p. 4) yang menunjukkan adanya pengaruh yang signifikan motivasi belajar terhadap prestasi belajar Mata Pelajaran Alquran Hadis.

Hasil penelitian di atas memberi gambaran jelas mengenai pengaruh motivasi belajar dan kegiatan ekstrakurikuler terhadap prestasi belajar siswa. Hasil-hasil penelitian tersebut menarik perhatian peneliti untuk mengetahui seberapa besar pengaruh motivasi belajar dan kegiatan ekstrakurikuler terhadap prestasi belajar khususnya pada mata pelajaran Alquran Hadis di Madrasah Aliyah, di mana kegiatan ekstrakurikuler yang diambil adalah yang terintegrasi dengan mata pelajaran Alquran Hadis.

Berdasarkan latar belakang masalah di atas, maka peneliti melakukan penelitian dengan judul "Pengaruh Motivasi Belajar dan Kegiatan Ekstrakurikuler Sanggar Alquran Terhadap Prestasi Belajar Siswa pada Mata Pelajaran Alquran Hadis di Madrasah Aliyah Kota Manado." Penelitian ini dilaksanakan pada tiga Madrasah Aliyah (MA) berbeda yang berada di Kota Manado, yakni MAN Model 1 Manado, MA Darul Istiqomah Manado dan MA PKP Manado.

\section{Kajian Teori}

\subsection{Konsep Motivasi Belajar}

Motivasi adalah dorongan yang timbul pada diri seseorang secara sadar atau tidak sadar untuk melakukan sesuatu tindakan yang dengan tujuan tertentu. Istilah motivasi dari kata motif yang dapat diartikan sebagai kekuatan yang menyebabkan individu tersebut bertindak. Motivasi juga diartikan, merupakan usaha-usaha yang menyebabkan seseorang atau kelompok orang tertentu tergerak melakukan sesuatu karena ingin mencapai tujuan yang dikehendaki atau mendapat kepuasan dengan perbuatannya (Uno, 2015).

Motivasi tumbuh didorong oleh kebutuhan (need) seseorang, seperti kebutuhan menjadi kaya, maka seseorang berusaha mencari penghasilan sebanyak-banyaknya. Kata motif diartikan sebagai daya upaya yang mendorong seseorang untuk melakukan sesuatu. Motif dapat dikatakan sebagai daya penggerak dari dalam dan di dalam subjek untuk melakukan aktivitas-aktivitas tertentu demi mencapai suatu tujuan (A.M., 2010).

Motivasi ini dapat juga dikaitkan dengan persoalan minat. Minat diartikan sebagai suatu kondisi yang terjadi apabila seseorang melihat ciri-ciri atau arti, sementara situasi yang dihubungkan dengan keinginan-keinginan atau kebutuhan-kebutuhannya sendiri (A.M., 2010). Oleh karena itu,apa yang dilihat seseorang sudah tentu akan membangkitkan minatnya sejauh apa yang dilihat itu mempunyai hubungan dengan kepentingannya sendiri. Menurut Sukmadinata (2005) istilah motivasi diartikan sebagai kekuatan yang menjadi pendorong kegiatan individu. Kekuatan tersebut menunjukkan suatu kondisi dalam diri individu untuk mendorong atau menggerakkan individu tersebut untuk mampu melakukan kegiatan mencapai sesuatu tujuan.

Dari beberapa definisi tersebut di atas, maka motivasi mengandung tiga komponen pokok, yaitu menggerakkan, mengalihkan, dan menopang tingkah laku manusia. Oleh karena itu, motivasi juga dipengaruhi oleh keadaan emosi seseorang. Secara umum dapat dikatakan bahwa tujuan motivasi adalah untuk menggerakkan atau menggugah seseorang agar timbul keinginan dan kemauan untuk melakukan sesuatu sehingga dapat memperoleh hasil atau mencapai tujuan tertentu. Kecenderungan sukses ditentukan oleh motivasi dan peluang serta intensif, begitu pula sebaliknya dengan kecenderungan untuk gagal.

Dalam hal ini Allah juga menengaskan dalam QS. Albaqarah: 286;

"Allah tidak membebani seseorang melainkan sesuai dengan kesanggupannya. Dia mendapat (pahala) dari (kebajikan) yang dikerjakanya dan ia mendapat (siksa) dari (kejahatan) yang diperbuatnya." (Kementerian Agama RI. 2012:286) 
Ayat di atas menjelaskan, "Allah tidak membebani seseorang melainkan sesuai dengan kesanggupannya", maksudnya Allah Shubhanahu wa ta'alla tidak membebani seseorang di luar batas kemampuannya. Ini menunjukan tentang kasih sayang Allah Swt., kepada para makhlukNya, serta kebaikan yang diberikan pada mereka (Asy-Syarqawi, 2013, p. 15). "Ia mendapat pahala (dari kebajikan) yang diusahakannya dan ia mendapat siksa (dari kejahatan) yang dikerjakannya", artinya ia akan memperoleh pahala dari kebaikan yang dulu pernah dilakukan, begitu pula akan mendapat siksa atas perbuatan jeleknya. Dan, semua itu, masih masuk pada kisaran amalan yang dibebankan pada mereka (Asy-Syarqawi, 2013, p. 15). Dalam konteks motivasi, ayat ini menjelaskan bahwa baik buruknya hasil yang diperoleh atau berhasil atau gagalnya seseorang, bergantung pada motivasi orang tersebut dalam melakukan sesuatu.

Jadi motivasi dalam hal ini sebenarnya merupakan respons dari suatu aksi, yakni tujuan. Motivasi memang muncul dari dalam diri manusia, tetapi kemunculannya karena terangsang/terdorong oleh adanya unsur lain, yaitu adanya tujuan. Tujuan ini akan menyangkut soal kebutuhan.

Berdasarkan konsep matovasi di atas, maka motivasi belajar pada dasarnya adalah usaha yang didasari untuk mengerahkan dan menjaga tingkah seseorang agar ia terdorong untuk bertindak melakukan sesuatu sehingga mencapai hasil atau tujuan tertentu. Motivasi belajar adalah suatu perubahan tenaga di dalam diri seseorang (pribadi) yang ditandai dengan timbulnya perasaan dan reaksi untuk mencapai tujuan. Motivasi belajar adalah kecenderungan siswa dalam melakukan kegiatan belajar yang didorong oleh hasrat untuk mencapai prestasi belajar sebaik mungkin.

Motivasi belajar juga merupakan kebutuhan untuk mengembangkan kemampuan diri secara optimum, sehingga mampu berbuat yang lebih baik, berprestasi dan kreatif. Motivasi belajar adalah suatu dorongan internal dan eksternal yang menyebabkan seseorang atau individu untuk bertindak atau mencapai tujuan, sehingga perubahan tingkah laku pada diri siswa diharapkan terjadi (Asy-Syarqawi, 2013, p. 15).

Menurut McDonald, mengatakan bahwa motivasi adalah suatu perbuatan energi di dalam pribadi seseorang yang ditandai dengan timbulnya afektif (perasaan) dan reaksi untuk mencapai tujuan. Perubahan energi dalam diri seseorang itu dapat berbentuk suatu aktivitas nyata berupa kegiatan fisik. Oleh karena seseorang mempunyai tujuan dalam aktivitasnya, maka seseorang mempunyai motivasi yang kuat untuk mencapainya dengan segala upaya yang dapat dia lakukan (McDonald, 1959, p. 173).

Kompri berpendapat bahwa motivasi dan belajar merupakan dua hal yang saling memengaruhi siswa untuk giat belajar jika ia mempunyai motivasi untuk belajar (Kompri, 2015, p. 229). Menurut Uno (2015, p. 23), motivasi belajar adalah perubahan tingkah laku secara relatif permanen dan secara potensial terjadi sebagai hasil dari praktik atau penguatan (reinforced practice) yang dilandasi keinginan untuk mencapai tujuan.

Jadi motivasi belajar adalah kondisi psikologis yang mendorong siswa untuk belajar secara sungguh-sungguh, yang pada gilirannya akan terbentuk cara belajar siswa yang sistematis, penuh konsentrasi dan dapat menyeleksi kegiatan-kegiatannya guna tercapainya tujuan yang dikehendakinya.

\subsection{Kegiatan Ekstrakurikuler Sanggar Alquran}

Kegiatan ekstrakurikuler merupakan kegiatan pengayaan dan perbaikan yang berkaitan dengan program kokurikuler dan intrakurikuler. Kegiatan ini dapat dijadikan sebagai wadah bagi siswa yang memiliki minat mengikuti kegiatan tersebut. Melalui bimbingan dan pelatihan guru, kegiatan ekstrakurikuler dapat membentuk sikap positif terhadap kegiatan yang diikuti oleh para siswa. Kegiatan ekstrakurikuler yang diikuti dan dilaksanakan oleh siswa baik di sekolah 
maupun di luar sekolah, bertujuan agar siswa dapat memperkaya dan memperluas diri. Memperluas diri ini dapat dilakukan dengan memperluas wawasan pengetahuan dan mendorong pembinaan sikap atau nilai-nilai.

Menurut Kamus Besar Bahasa Indonesia, ekstrakurikuler yaitu suatu kegiatan yang berada di luar program yang tertulis di dalam kurikulum seperti latihan kepemimpinan dan pembinaan siswa (Departemen Pendidikan Nasional, 2005). Kegiatan ekstrakurikuler sendiri dilaksanakan di luar jam pelajaran wajib. Kegiatan ini memberi keleluasaan waktu dan memberikan kebebasan pada siswa, terutama dalam menentukan jenis kegiatan yang sesuai dengan bakat serta minat mereka. Antara kegiatan intrakurikuler dan ekstrakurikuler sesungguhnya tidak dapat dipisahkan, bahkan kegiatan ekstrakurikuler perpanjangan pelengkap atau penguat kegiatan intrakurikuler untuk menyalurkan bakat atau pendorong perkembangan potensi anak didik mencapai tarap maksimum (Departemen Pendidikan Nasional, 2005).

Sehubungan dengan penjelasan tersebut, dapat penulis kemukakan bahwa kegiatan ekstrakurikuler merupakan kegiatan yang menekankan kepada kebutuhan siswa agar menambah wawasan, sikap dan keterampilan siswa baik di luar jam pelajaran wajib serta kegiatannya yang dilakukan di dalam dan di luar sekolah.

Menurut Kamus Besar Bahasa Indonesia, bahwa kata sanggar memiliki arti tempat untuk melakukan kegiatan seni (Departemen Pendidikan Nasional, 2005). Dengan kata lain, istilah sanggar dapat diartikan sebagai sebuah tempat atau sarana yang di-gunakan oleh suatu komunitas atau sekelompok orang untuk berkegiatan seni seperti seni tari, seni lukis, seni kerajinan, seni peran, dan lain-lain. Kegiatan yang ada dalam sebuah sanggar berupa kegiatan pembelajaran tentang seni, yang meliputi proses dari pembelajaran, penciptaan, hingga produksi. Semua proses hampir sebagian besar dilakukan di dalam sanggar (Alfred, 2013).

Sanggar Alquran adalah lembaga atau kelompok masyarakat yang menyelenggarakan pendidikan nonformal jenis keagamaan Islam yang bertujuan untuk memberikan pengajaran membaca Alquran, serta memahami dasar-dasar dinul Islam pada anak usia taman kanak-kanak, sekolah dasar dan atau madrasah ibtidaiyah (SD/MI) atau yang lebih tinggi (madrasah tsanawiyah dan madrasah Aliyah) (Nurkarima, 2012).

Keberadaan sanggar Alquran membawa misi yang sangat mendasar terkait dengan pentingnya menanamkan nilai-nilai Alquran. Dengan demikian, sanggar Alquran bertujuan menyiapkan anak didiknya agar menjadi generasi muslim Qurani, yaitu generasi yang mencintai Alquran sebagai bacaan dan sekaligus pandangan hidupnya sehari-hari (Nurkarima, 2012).

Kegiatan-kegiatan yang dilaksanakan dalam sanggar Alquran adalahtahsin Quran (tilawah), khottil Quran, tahfiz Quran, dan fahmil Quran (Ridwan, 2007). Keempat kegiatan tersebut adalah:

1. Tahsin Quran (Tilawah). Tahsin merupakan definisi dari tajwid secara bahasa yang berarti membaguskan, yang berarti berupaya untuk menjadikan baik. Secara leksikal tahsin berarti membaguskan bacaan Alquran atau de-ngan kata lain membaca Alquran dengan sebaik-baiknya. Tentu saja untuk mencapainya berarti dengan menggunakan ilmu tajwid-tahsin adalah mem-baca Alquran dengan menggunakan kaidah-kaidah ilmu tajwid;

2. Khottil Quran. Khottil Qur'an merupakan pembagusan dari segi tulisan ayat ayat Allah;

3. Tahfiz Quran. Tahfiz berasal dari kata hafazo yang berarti menjaga. Tahfidz termasuk kepada mashdar yang berarti menjaga dengan sangat. Adapun makna yang dimaksud di sini adalah menghafal Alquran;

4. Fahmil Quran. Fahmil Quran yaitu pemahaman yang menekankan pada isi kandungan Alquran. 


\subsection{Belajar}

\subsubsection{Prestasi Belajar}

Menurut Dimyati dan Mudjiono, belajar merupakan hal yang kompleks yang dapat dipandang dari dua aspek, yaitu dari aspek siswa dan dari guru. Dari segi siswa, belajar dialami sebagai suatu proses siswa mengalami proses mental dalam menghadapi bahan belajar dari segi guru proses belajar tersebut tampak sebagai perilaku tentang suatu hal. Belajar merupakan proses internal yang kompleks yang meliputi seluruh ranah, yaitu kognitif, afektif, dan psikomotorik. Dalam belajar siswa akan mengalami proses perubahan tingkah laku baik itu kognitif, afektif, maupun psi-komotorik (Dimyati \& Mujiono, 2002).

Prestasi adalah hasil dari suatu kegiatan yang telah dikerjakan, diciptakan, baik secara individual maupun kelompok. Prestasi tidak akan pernah dihasilkan selama seseorang tidak melaksanakan suatu kegiatan. Dalam kenyataan, untuk mendapatkan prestasi tidak semudah dengan yang dibayangkan, tetapi penuh perjuangan dengan berbagai tantangan yang harus dihadapi untuk mencapainya.

Poerwadarminta (2007, p. 21) mendefinisikan prestasi sebagai hasil yang telah dicapai (dilakukan, dikerjakan, dan sebagainya). Sedangkan menurut Mas'ud Khasan Abdul Qohar, prestasi adalah apa yang telah diciptakan, hasil pekerjaan, hasil yang menyenangkan hati yang diperoleh dengan jalan keuletan kerja (Mas'ud, 1998, p. 74).

Dalam proses belajar mengajar, potensi yang dimiliki setiap anak diarahkan dan dikembangkan melalui berbagai kegiatan sehingga menghasilkan prestasi belajar.

Penguasaan siswa terhadap pengetahuan (kognitif), nilai dan sikap (afektif), serta keterampilan (psikomotorik) dengan baik menunjukkan keberhasilan yang dicapainya. Keberhasilan inilah yang dalam dunia pendidikan disebut dengan prestasi belajar. Prestasi belajar adalah penguasaan pengetahuan atau keterampilan yang dikembang-kan oleh suatu mata pelajaran yang lazimnya ditunjukkan dengan nilai test atau angka nilai yang diberikan oleh pendidik (H. Gunawan, 2012).

Syamsuddin menjelaskan bahwa dimaksud dengan prestasi belajar adalah kecakapan nyata (actual ability) yang menunjukkan kepada aspek kecakapan yang segera dapat didemonstrasikan dan diuji sekarang juga atau dengan kata lain prestasi belajar adalah kemampuan seseorang dalam menguasai suatu masalah setelah melalui ujian tertentu (Makmun, 1983).

Berdasarkan pengertian di atas, maka dapat disimpulkan bahwa Prestasi belajar adalah tingkat keberhasilan yang dicapai siswa dalam kurun waktu proses belajar tertentu yang dapat diketahui dengan hasil evaluasi yang dilaksanakan oleh pendidik. Prestasi yang dicapai oleh siswa merupakan hasil dan potensi yang dimilikinya. Prestasi belajar merupakan suatu masalah yang sangat penting karena dengan kehadiran prestasi belajar dapat memberikan kepuasan apalagi siswa yang bersekolah. Prestasi belajar adalah serangkaian proses kegiatan belajar yang disengaja dan dilakukan secara sadar.

Meski demikian, tidak semua proses belajar menghasilkan prestasi yang baik, sebab dalam kegiatan pembelajaran di sekolah banyak hal yang terjadi dengan berbagai keanekaragaman masalah pada masing-masing siswa. Ada siswa yang dapat menempuh kegiatan belajarnya secara lancar dan berhasil tanpa mengalami kesulitan berarti, namun di sisi lain tidak sedikit pula siswa yang justru dalam belajarnya mengalami berbagai kesulitan. Kesulitan belajar siswa ditunjukan dengan adanya hambatan-hambatan tertentu untuk mencapai prestasi belajar, sehingga pada akhirnya dapat menyebabkan prestasi belajar yang dicapainya berada di bawah dari yang semestinya. 


\subsubsection{Indikator Prestasi Belajar}

Pada dasarnya, pengungkapan prestasi belajar yang ideal meliputi segenap ranah psikologis yang berubah sebagai akibat pengalaman dan proses belajar siswa. Bentuk perubahan tingkah laku secara integral sebagai prestasi belajar dapat digolongkan ke dalam tiga jenis klasifikasi. Sebagaimana yang diungkapkan Bloom yang kemudian dikenal popular dengan teori "Taxonomy Bloom" mengungkapkan ke-tiga jenis prestasi belajar, yakni 1) kemampuan kognitif, 2) kemampuan afektif, dan 3) kemampuan psikomotorik (Bloom, 1989, p. 279). Dalam penelitian ini prestasi yang diteliti adalah pada ranah kemampuan kognitif.

Sementara itu untuk mengetahui tingkat keberhasilan anak dalam mengikuti proses pendidikan dan pembelajaran, maka dapat diperhatikan berdasarkan indikator atau kondisi yang telah berhasil dicapai oleh siswa. Indikator prestasi belajar siswa dapat dilihat berdasarkan beberapa hal yaitu:

\subsubsection{Kemampuan dalam Bidang Kognitif}

Domain kognitif ini berkenaan dengan perilaku yang berhubungan dengan berpikir, mengetahui dan memecahkan masalah. Domain ini memiliki enam tingkatan yang kini dikenal dengan Revisi Taksonomi Bloom, yang merupakan perbaikan dari taksonomi bloom yang sebelumnya. Keenam tingkatan Revisi Taksonomi Bloom tersebut terdiri atas mengingat (remember), memahami/mengerti (understand), menerapkan (apply), menganalisis (analyze), mengevaluasi (evaluate), dan menciptakan (create). Terkait dengan tingkatan ranah kognitif ini, untuk lebih jelasnya, dilihat dalam tabel berikut berikut (I. Gunawan \& Palupi, 2012, pp. 105, 108):

Tabel 1: RevisiTaksonomi Anderson dan Krathwohl

\begin{tabular}{|c|l|l|}
\hline Tingkatan & \multicolumn{1}{|c|}{ Berpikir Tingkat Tinggi } & $\begin{array}{c}\text { Komunikasi } \\
\text { (communication spectrum) }\end{array}$ \\
\hline $\begin{array}{c}\text { Menciptakan } \\
\text { (Creating) } \\
\text { (C6) }\end{array}$ & $\begin{array}{l}\text { Menggeneralisasikan } \\
\text { (generating), merancang } \\
\text { (designing), memproduksi } \\
\text { (producing), merencanakan } \\
\text { kembali (devising) }\end{array}$ & $\begin{array}{l}\text { Negosiasi (negotiating), } \\
\text { memoderatori (moderating), } \\
\text { kolaborasi (collaborating) }\end{array}$ \\
\hline $\begin{array}{c}\text { Mengevaluasi } \\
\text { (Evaluating) } \\
\text { (C5) }\end{array}$ & $\begin{array}{l}\text { Mengecek (checking), mengkritisi } \\
\text { (critiquing), hipotesa } \\
\text { (hypothesising), eksperimen } \\
\text { (experimenting) }\end{array}$ & $\begin{array}{l}\text { Bertemu dengan jaringan/ } \\
\text { mendiskusikan (net } \\
\text { meeting), berkomentar } \\
\text { (commenting), berdebat } \\
\text { (debating) }\end{array}$ \\
\hline $\begin{array}{c}\text { Menganalisis } \\
\text { (Analyzing) } \\
\text { (C4) }\end{array}$ & $\begin{array}{l}\text { Memberi atribut (attributeing), } \\
\text { mengorganisasikan (organizing), } \\
\text { mengintegrasikan (integrating), } \\
\text { mensahihkan (validating) }\end{array}$ & $\begin{array}{l}\text { Menanyakan (Questioning), } \\
\text { meninjau ulang (reviewing) }\end{array}$ \\
\hline $\begin{array}{c}\text { Menerapkan } \\
\text { (Applying) } \\
\text { (C3) }\end{array}$ & $\begin{array}{l}\text { Menjalankan prosedur } \\
\text { (executing), } \\
\text { mengimplementasikan } \\
\text { (implementing), menyebarkan } \\
\text { (sharing), }\end{array}$ & $\begin{array}{l}\text { Posting, blogging, } \\
\text { menjawab (replying) }\end{array}$ \\
\hline $\begin{array}{c}\text { Memahami/men } \\
\text { gerti }\end{array}$ & $\begin{array}{l}\text { Mengklasifikasikan } \\
\text { (classification), membandingkan }\end{array}$ & $\begin{array}{l}\text { Bercakap (chatting), } \\
\text { menyumbang }\end{array}$ \\
\hline
\end{tabular}




\begin{tabular}{|c|l|l|}
\hline $\begin{array}{c}\text { (Understanding) } \\
(\mathrm{C} 2)\end{array}$ & $\begin{array}{l}\text { (comparing), menginterpretasikan } \\
\text { (interpreting), berpendapat } \\
\text { (inferring) }\end{array}$ & (contributing), networking, \\
\hline $\begin{array}{c}\text { Mengingat } \\
\text { Remembering) } \\
(\mathrm{C} 1)\end{array}$ & $\begin{array}{l}\text { Mengenali (recognition), } \\
\text { memanggil kembali (recalling), } \\
\text { mendeskripsikan (describing), } \\
\text { mengidentifikasi (identifying) }\end{array}$ & $\begin{array}{l}\text { Menulis teks (texting), } \\
\text { mengirim pesan singkat } \\
\text { (instant messaging), } \\
\text { berbicara (twittering) }\end{array}$ \\
\hline \multicolumn{2}{|c|}{ Berpikir Tingkat Rendah } \\
\hline
\end{tabular}

\subsubsection{Kemampuan dalam Bidang Afektif}

Domain afektif yaitu ranah yang berkaitan dengan aspek-aspek emosional (emotional), seperti: perasaan (feeling), minat (interes), sikap (attitude), kepatuhan moral dan sebagainya. Yang termasuk dalam domain afektif adalah penerimaan (receiving/attending), sambutan (responding), penilaian (valuing) dan pengorganisasian (organization), dan karakterisasi (characterization) (Bloom, 1989, p. 217). Prestasi afektif ini merupakan indikator keberhasilan bagi proses pendidikan dan pembelajaran. Dengan memerhatikan tingkat perubahan terjadi pada kompetensi afektif ini, maka dapat diketahui tingkat keberhasilan proses pembelajaran.

\subsubsection{Prestasi dalam Bidang Psikomotorik}

Domain psikomotorik yaitu ranah yang berkaitan dengan aspek-aspek keterampilan (skill) yang melibatkan fungsi sistem syaraf dan otot (neuromascular system) dan fungsi psikis. Ranah ini terdiri atas (a) kesiapan (readiness), meniru (imitation), membiasakan (habitual), menyesuaikan (adaptation), dan menciptakan (organitation) (Bloom, 1989, p. 219).

Aspek psikomotorik sangat penting dalam proses pendidikan dan pembelajaran se-bab aspek ini merupakan salah satu indikator prestasi belajar siswa. Semakin bagus tingkat perubahan keterampilan siswa, semakin berhasil proses pendidikan dan pembelajaran yang diikutinya.

\section{Metode Penelitian}

Penelitian ini dilakukan di tiga lokasi berbeda yakni di MAN Model 1 Manado, MA Darul Istiqomah, dan MA PKP,yang dilaksanakan selama tiga bulan, selang bulan Mei sampai dengan Juli 2017 mulai dari pengumpulan data sampai dengan pengolahan data.

Populasi dalam penelitian ini adalah seluruh siswa madrasah Aliyah di Kota Manado tahun pelajaran 2016/2017 yang mengikuti kegiatan ekstrakurikuler sanggar Alquran, yatu sebanyak 300 orang siswa. Untuk menentukan sampel penelitian, peneliti menggunakan tabel yang dikembangkan dari rumus Isaac dan Michael, di mana berdasarkan tabel tersebut untuk populasi yang berjumlah 300 orang maka sampelnya berjumlah 161 orang dengan taraf kesalahan 5\% (Sugiyono, 2010:128). Dengan demikian, dalam penelitian ini dipilih sebanyak 161 Siswa sebagai sampel yang tersebar pada 3 (tiga) sekolah Madrasah Aliyah yang ada di Kota Manado yang diambil dengan metode purposive sampling.

Metode penelitian yang digunakan dalam penelitian ini adalah survai dengan pendekatan kuantitatif. Penelitian dengan pendekatan kuantitatif ini mendasarkan kajian pada prinsip rasional empirik. Paradigma kuantitatif menekankan pada pengujian teori melalui pengukuran variabel penelitian dengan angka dan melakukan analisis data dengan prosedur statistik. Penelitian yang menggunakan pendekatan deduktif bertujuan menguji hipotesis penelitian menggunakan paradigma kuantitatif. 
Metode survai yang digunakan bersifat expost facto yang digunakan untuk menjelaskan hubungan kausal dan menguji hipotesis. Penelitian survai dapat digunakan untuk maksud (1) penjajagan (eksploratif), (2) deskriptif, (3) penjelasan (eksplanatory atau confirmatory), yakni menjelaskan hubungan kausal dan penguji hipotesis; (4) evaluasi, (5) prediksi atau ramalan kejadian tertentu di masa yang akan datang (6) penelitian oprasional, dan (7) pengembangan indikator-indikator (Singarimbun \& Effendi, 2003, p. 21).

Penelitian ini menggunakan desain penelitian kuantitatif untuk meneliti pada populasi atau sampel tertentu. Teknik pengambilan sampel pada umumnya dilakukan secara acak atau random, pengumpulan data menggunakan instrumen penelitian, analisis data bersifat kuantitatif/statistik dengan tujuan menguji hipotesis yang telah ditetapkan (Sugiyono, 2002, p. 14).

Untuk mengukur variabel dalam penelitian ini digunakan instrumen berupa angket (kuesioner) dan tes. Instrumen untuk menggali data responden disusun dan dijabarkan dalam bentuk indikator dan pertanyaan dengan kategori-kategori menggunakan skala Likert, sedangkan tes digunakan untuk mengumpulkan data-data tentang prestasi belajar Alquran Hadis siswa Madrasah Aliyah di Kota Manado.

Pengujian hipotesis dalam penelitian ini dilakukan dengan menggunakan teknik analisis regresi ganda. Teknik ini digunakan untuk mengukur pengaruh dari variabel bebas (independent) terhadap variabel terikat (dependent), yaitu pengaruh motivasi belajar siswa (X1) dan kegiatan ekstrakurikuler sanggar Alquran(X2) terhadap pres-tasi belajar siswa pada mata pelajaran Alquran Hadis (Y). Analisis regresi multiple (regresi ganda) dengan persamaan (Sudjana, 2012, p. 332):

$$
\hat{\mathrm{Y}}=\mathrm{a}_{0}+\mathrm{a}_{1} \mathrm{X}_{1}+\mathrm{a}_{2} \mathrm{X}_{2}+\ldots+\mathrm{a}_{\mathrm{k}} \mathrm{X}_{\mathrm{k}}
$$

Keterangan:

$\hat{\mathrm{Y}}=$ Prestasi belajar siswa

$\mathrm{a}=$ Konstanta

$\mathrm{X}_{1}=\quad$ Motivasi belajar

$\mathrm{X}_{2}=\quad$ Kegiatan ekstrakurikuler sanggar Alquran

Untuk menguji keberartian regresi multiple digunakan uji $\mathrm{F}$ dengan rumus:

$$
\mathrm{F}=\frac{J K_{r e g} / k}{J K_{r e s} /(n-k-1)}
$$

Keterangan:

$\mathrm{k}=$ banyaknya variabel bebas

$\mathrm{n}=$ banyaknya sampel (Sugiyono, 2002, p. 44).

Uji hipotesis dengan teknik analisis regresi ganda dilakukan menggunakan Statis-tical Package for Sosial Science (SPSS) 23, Untuk menguji signifikansi koefisien regresi, dilakukan uji keberartian koefisien regresi sebagai berikut:

\subsection{Uji Parsial (uji t)}

Uji parsial (uji t) digunakan untuk menguji pengaruh masing-masing variabel independen (motivasi belajar dan kegiatan ekstrakurikuler sanggar Alquran) terhadap variabel 
dependen (prestasi belajar siswa). Kaidah pengambilan keputusan dalam uji t dengan menggunakan SPSS adalah:

Jika probabilitas $>0,05$ maka Ho diterima

Jika probabilitas $<0,05$ maka Ho ditolak

\subsection{Uji Simultan}

Uji simultan (uji F) ini digunakan untuk menguji pengaruh variabel independen (motivasi belajar siswa dan kegiatan ekstrakurikuler sanggar Alquran) terhadap variabel dependen (prestasi belajar siswa) secara bersama-sama (simultan) dengan tingkat signifikan yang digunakan sebesar $\alpha=5 \%$ dan df (k: n-k-1). Kaidah pengambilan keputusan dalam uji $\mathrm{F}$ dengan menggunakan SPSS adalah:

Jika probabilitas $>0,05$ maka Ho diterima

Jika probabilitas $<0,05$ maka Ho ditolak

(Sugiyono, 2002, p. 71).

Prinsip pengujian ini adalah uji statistik parametrik, sehingga sebelum dilakukan pengujian, terlebih dahulu harus dilakukan uji prasyarat analisis yaitu uji normalitas data. Selain itu juga karena pengujian ini menggunakan uji regresi, maka dilakukan uji ekonometrik yaitu uji heteroskedastisitas, multikolinearitas, autokorelasi, dan linearitas regresi (Sugiyono, 2002).

\section{Hasil dan Pembahasan}

Pengujian hipotesis dalam penelitian ini bertujuan untuk menguji tiga hipotesis yang telah dirumuskan sebelumnya, yaitu: (1) terdapat pengaruh yang signifikan motivasi belajar siiswa terhadap prestasi belajar siswa Madrasah Aliyah di Kota Manado pada mata pelajaran Alquran Hadis, (2) terdapat pengaruh yang siginfikan kegiatan ekstrakurikuler sanggar Alquran terhadap prestasi belajar siswa Madrasah Aliyah di Kota Manado pada mata pelajaran Alquran Hadis, dan (3) terdapat pegaruh yang signifikan motivasi belajar siswa dan kegiatan ekstrakurikuler sanggar Alquran secara bersama-sama terhadap prestasi belajar siswa Madrasah Aliyah di Kota Manado pada mata pelajaran Alquran Hadis.

Ketiga hipotesis tersebut dianalisis dengan menggunakan uji regresi ganda (multiple regression), dengan uji signifikansi $t$ (parsial) untuk menganalisis hipotesis pertama dan kedua, dan uji signifikansi $\mathrm{F}$ (simultan) untuk menguji hipotesis ketiga. Berdasarkan pada pengujian persyaratan analisis statistik sebagai syarat pemberlakuan pengujian hipotesis penelitian menunjukkan bahwa hipotesis-hipotesis penelitian ini dapat diuji keberartian atau kebermaknaannya terutama dengan menerapkan analisis regresi.

Dengan menggunakan SPSS for Windows Versi 23.0, hasil uji regresi ganda dapat dilihat pada tabel berikut ini: 
Tabel 2: Hasil Analisis Regresi Linear Berganda Antara Motivasi Belajar Siswa dan Kegiatan Ekstrakurikuler Sanggar Alquran dengan Prestasi Belajar Siswa

\begin{tabular}{|c|c|c|c|c|c|}
\hline \multirow[b]{2}{*}{ Model } & \multicolumn{2}{|c|}{$\begin{array}{l}\text { Unstandardized } \\
\text { Coefficients }\end{array}$} & $\begin{array}{l}\text { Standa } \\
\text { rdized } \\
\text { Coeffi } \\
\text { cients } \\
\end{array}$ & $\mathrm{T}$ & Sig. \\
\hline & B & $\begin{array}{l}\text { Std. } \\
\text { Error }\end{array}$ & Beta & & \\
\hline (Constant) & 87,768 & 14,207 & & $-6,178$ & ,000 \\
\hline $\begin{array}{l}\text { Motivasi } \\
\text { Belajar Siswa }\end{array}$ & 671 & ,213 & ,377 & 3,155 & ,002 \\
\hline $\begin{array}{l}\text { Kegiatan } \\
\text { Ekstrakurikul } \\
\text { er Sanggar } \\
\text { Alquran }\end{array}$ & ,639 & ,222 & ,344 & 2,882 & ,005 \\
\hline
\end{tabular}

a. Dependent Variable: Prestasi Belajar Siswa

Dari tabel hasil analisis regresi ganda di atas, maka persamaan regresi ganda dalam penelitian ini adalah:

$$
Y=-87,768+0,671 X 1+0,639 X 2
$$

Dari persamaan regresi yang diperoleh tersebut, dapat dijelaskan hal-hal sebagai berikut:

a. Nilai konstanta sebesar -87,768, menyatakan bahwa jika variabel Prestasi Belajar Siswa (Y) tidak dipengaruhi oleh kedua variabel bebasnya atau Moti-vasi Belajar Siswa (X1) dan Kegiatan Ekstrakurikuler Sanggar Alquran (X2) bernilai nol, maka besarnya ratarata Prestasi Belajar Siswa akan bernilai $-87,768$.

b. Koefisien regresi untuk variabel bebas X1 (Motivasi Belajar Siswa) bernilai positif, menunjukkan adanya hubungan yang searah antara motivasi belajar siswa (X1) dengan prestasi belajar siswa (Y). Koefisien regresi variabel X1 sebesar 0.671yang menunjukkan bahwa untuk setiap pertambahan skor moti-vasi belajar siswa (X1) sebesar satu satuan akan menyebabkan meningkatnya prestasi belajar siswa (Y) sebesar 0.671 .

Koefisien regresi untuk variabel bebas X2 (Kegiatan Ekstrakurikuler Sanggar Alquran) bernilai positif, menunjukkan adanya hubungan yang searah antara kegiatan ekstrakurikuler sanggar Alquran (X2) dengan prestasi belajar (Y). Koefisien regresi variabel X2 sebesar 0,639 menunjukkan bahwa untuk setiap peningkatankegiatan ekstrakurikuler sanggar Alquran (X2) sebesar satu satuan akan menyebabkan meningkatnya prestasi belajar siswa (Y) sebesar 0,639. 


\subsection{Uji Hipotesis}

\subsubsection{Pengujian Hipotesis Secara Parsial (Uji $t$ )}

Uji t bertujuan untuk membuktikan apakah variabel-variabel independen secara individu berpengaruh terhadap return saham atau yang lebih dikenal secara parsial. Kriteria pengujian dari uji t jika signifikansi $>0,05$, maka $\mathrm{H} 0$ diterima dan jika signifikan $<0,05$, maka H0 ditolak.

\subsubsection{Pengaruh motivasi belajar terhadap prestasi belajar siswa}

Berdasarkan hasil uji regresi ganda pada Tabel 1 di atas, di-peroleh nilai t hitung untuk variabel X1 terhadap Y sebesar 3,115 dengan nilai signi-fikansi (Sig.) $=0,002$. Nilai signifikansi ini lebih kecil dari $\alpha=0,05$, sehingga dengan demikian dapat disimpulkan bahwa motivasi belajar berpengaruh secara signifikan terhadap prestasi belajar siswa.

\subsubsection{Pengaruh kegiatan ekstrakurikuler sanggar Alquran terhadap prestasi belajar siswa}

Berdasarkan hasil uji regresi ganda pada Tabel 1 di atas, diperoleh nilai t hitung untuk variabel X2 terhadap Y sebesar 2,882 dengan nilai signi-fikansi (Sig.) $=0,005$. Nilai signifikansi ini lebih kecil dari $\alpha=0,05$, dengan demikian dapat disimpulkan bahwa kegiatan ekstrakurikuler sanggar Alquran berpengaruh secara signifikan terhadap prestasi belajar siswa.

\subsubsection{Pengujian Hipotesis Secara Simultan (Uji $F$ )}

Berdasarkan hasil pengujian hipotesis dengan perhitungan analisis regresi berganda menggunakan program komputasi SPSS for Windows 23, hasil uji $\mathrm{F}$ dapat dilihat pada tabel berikut:

Tabel 3: Hasil Uji F

\begin{tabular}{|c|c|c|c|c|c|}
\hline \multicolumn{6}{|c|}{ ANOVA } \\
\hline Model & \begin{tabular}{l|l} 
Sum of \\
Squares
\end{tabular} & Df & $\begin{array}{l}\text { Mean } \\
\text { Square }\end{array}$ & $\mathrm{F}$ & Sig. \\
\hline Regression & 33167,19 & 2 & 16583,595 & 75,602 &, $000^{\mathrm{b}}$ \\
\hline Residual & 34657,92 & 158 & 219,354 & & \\
\hline Total & 67825,12 & 160 & & & \\
\hline \multicolumn{6}{|c|}{ a. Dependent Variable: Prestasi Belajar Siswa } \\
\hline \multicolumn{6}{|c|}{$\begin{array}{l}\text { b. Predictors: (Constant), Kegiatan Ekstrakurikuler Sanggar Alquran, } \\
\text { Motivasi Belajar Siswa }\end{array}$} \\
\hline
\end{tabular}

Dari tabel ANOVA di atas, diperoleh nilai F sebesar 75,602 dengan signifikansi (Sig.) = 0,000 , di mana nilai signifikansi ini lebih kecil dibandingkan dengan nilai $\alpha=0,05$. Hasil ini menunjukkan bahwa variabel-variabel independen penelitian, yaitu motivasi belajar siswa (X1) dan kegiatan ekstrakurikuler sanggar Alquran (X2) secara simultan berpengaruh signifikan terhadap prestasi belajar siswa.

\subsubsection{Koefisien Determinasi $\left(\mathbf{R}^{2}\right)$}

Pengujian ini dilakukan untuk mengetahui kemampuan dari variabel-variabel independen yang ada menjelaskan variabel dependen. Koefisien determi-nasi memiliki besaran angka 0 hingga 1, apabila hasil dari pengujian tersebut mendekati 1 maka dapat dikatakan bahwa varia- 
bel independen memberikan informasi yang semakin mampu menjelaskan variabel dependen. Berikut hasil dari uji koefisien determinasi:

Tabel 4: Hasil Perhitungan Koefisien Determinasi

\begin{tabular}{|c|r|r|r|r|}
\hline Model & \multirow{2}{*}{ R } & R Square & $\begin{array}{c}\text { Adjusted } \\
\text { R Square }\end{array}$ & $\begin{array}{c}\text { Std. Error of the } \\
\text { Estimate }\end{array}$ \\
\hline 1 &, $699^{\mathrm{a}}$ &, 489 &, 483 & 14,811 \\
\hline
\end{tabular}

Berdasarkan hasil uji koefisien determinasi di atas dapat dilihat bahwa nilai R se-besar 0,699 yang berarti bahwa korelasi antara variabel bebas dan variabel terikat cu-kup kuat, yang didasarkan pada nilai $\mathrm{R}$ yang berada di atas 0,5 . Nilai $\mathrm{R}^{2}$ yang diper-oleh sebesar 0,489 , yang mengindikasikan bahwa kemampuan variabel-variabel in-dependen (motivasi belajar siswa dan kegiatan ekstrakurikuler sanggar Alquran) mampu menjelaskan sebesar 48,9\% variasi variabel dependennya (prestasi belajar siswa), sedangkan sisanya sebesar $51,1 \%$ dijelaskan atau dipengaruhi variabel lain yang tidak dimasukan dalam model penelitian ini.

\subsection{Pembahasan}

Dari hasil uji $t$ (parsial) terhadap koefisien regresi ganda, diperoleh hasil $t$ hitung untuk variabel motivasi belajar siswa signifikan pada taraf nyata $\alpha=0,05$, sehingga dapat disimpulkan bahwa motivasi belajar siswa memberikan pengaruh yang signifikan terhadap prestasi belajar siswa Madrasah Aliyah Kota Manado pada mata pelajaran Alquran Hadis. Selanjutnya karena $t$ hitung yang diperoleh bernilai positif, dapat disimpulkan bahwa semakin tinggi motivasi belajar yang dimiliki siswa, maka akan menyebabkan semakin tingginya hasil belajar Alquran Hadis yang diraih siswa, dan sebaliknya semakin rendah motivasi belajar siswa maka akan berpengaruh dengan semakin rendahnya hasil belajar siswa.

Hasil penelitian ini didukung oleh pendapat Sukmadinata (2005:163) yang mengatakan bahwa belajar perlu didukung oleh motivasi yang kuat dan konstan. Motivasi yang lemah serta tidak konstan akan menyababkan kurangnya usaha belajar yang pada akhirnya akan berpengaruh terhadap hasil belajar. Motivasi belajar yang kuat mendorong peserta didik untuk melakukan usaha belajar untuk meraih yang apa yang diinginkan dari hasil belajar. Sebaliknya rendahnya motivasi belajar kurangnya upaya untuk mencapai prestasi belajar yang diinginkan.

Dalam konteks pembelajaran, motivasi merupakan faktor penting karena dapat menggerakkan perilaku siswa kearah yang positif sehingga mampu menghadapi segala tuntutan, kesulitan serta mampu menanggung risiko dalam studinya. Motivasi dapat menentukan baik tidaknya dalam mencapai tujuan sehingga semakin besar motivasinya akan semakin besar kesuksesan belajarnya. Senada dengan yang dikemukakan Ngalim Purwanto (n.d., p. 27) bahwa tiga fungsi motivasi, yaitu: 1) mendorong siswa untuk berbuat; 2) menentukan arah perbuatan; 3) menyeleksi perbuatan.

Demikian halnya dengan kegiatan ekstrakurikuler sanggar Alquran. Dari hasil pengujian regresi ganda, dapat disimpulkan bahwa kegiatan ekstrakurikuler sanggar Alquran memberikan pengaruh yang signifikan terhadap prestasi belajar siswa Madrasah Aliyah Kota Manado pada mata pelajaran Alquran Hadis. Nilai $t$ hitung yang diperoleh juga bernilai positif, sehingga dapat disimpulkan bahwa semakin tinggi keaktifan siswa dalam mengikuti kegiatan ekstrakurikuler sanggar Alquran, maka akan menyebabkan semakin tingginya hasil belajar Alquran Hadis yang diraih siswa. 
Pengaruh yang signifikan dari kegiatan ekstrakurikuler sanggar Alquran terhadap prestasi belajar siswa menunjukkan bahwa tingginya prestasi belajar siswa Madrasah Aliyah di Kota Manado pada mata pelajaran Alquran Hadis turut dipengaruhi oleh keaktifan siswa dalam mengikuti kegiatan ekstrakurikuler sanggar Alquran. Hal ini disebabkan karena siswa dapat mengambil nilai-nilai positif dari keaktifan mereka dalam kegiatan ekstrakurikuler yang diikutinya, dalam hal ini sanggar seni Alquran sehingga dapat mencapai prestasi belajar sesuai dengan yang diharapkan.

Hasil penelitian ini sejalan dengan penelitian yang dilakukan oleh Handoko (1992), yang menyipulkan bahwa bahwa keaktifan siswa dalam kegiatan ekstrakurikuler mempunyai pengaruh yang positif terhadap prestasi belajar siswa. Pengaruh yang signfikan ini disebabkan karena siswa yang aktif dalam kegiatan ekstrakurikuler akan dapat mengambil nilai-nilai positif dari kegiatan yang diikutinya sehingga akan dapat mencapai prestasi belajar sesuai dengan yang diharapkannya.

Pengaruh kegiatan ekstrakurikuler sanggar Alquran terhadap prestasi belajar siswa dalam mata pelajaran Alquran Hadis meruapakan manifestasi dari iklim persaingan yang tercipta antar siswa dalam kegiatan ekstrakurikuler yang tetap kompetitif akan tetapi dengan suasana yang lebih fleksibel dan comfortable, sehingga para siswa tetap terpacu untuk menjadi yang terbaik dengan suasana hati yang nyaman untuk mencapainya. Kegiatan ekstrakurikuler yang terintegrasi dengan mata pelajaran Alquran Hadis juga membantu para siswa untuk mendalami materi pelajaran secara lebih intensif, sehingga mempertajam pemahaman materi pelajaran yang diberikan secara reguler di sekolah, yang kemudian dapat meningkatkan prestasi belajar mereka dalam mata pelajaran Alquran Hadis. Hal ini sesuai dengan apa yang dikemukakan oleh (Martani, 2015) bahwa hasil yang dicapai siswa setelah mengikuti pelajaran ekstrakurikuler akan berdampak pada hasil belajar di ruang kelas yaitu pada mata pelajaran tertentu yang ada hubungannya dengan ekstrakurikuler yang diikuti yang dapat meningkatkan prestasi belajar mereka dalam mata pelajaran tersebut.

Dari hasil uji F (simultan) pada analisis regresi ganda diperolehkesimpulan bahwa motivasi belajar siswa dan kegiatan ekstrakurikuler sanggar Alquran secara bersama-sama berpengaruh signifikan terhadap prestasi belajar siswa. Nilai $\mathrm{R}^{2}$ yang diperoleh sebesar 0,489 , di mana hasil ini mengindikasikan bahwa motivasi belajar siswa dan kegiatan ekstrakurikuler sanggar Alquran mampu menjelaskan sebesar $48,9 \%$ variasi prestasi belajar siswa, sedangkan sisanya sebesar $51,1 \%$ dijelaskan atau dipengaruhi variabel lain.

Hasil penelitian ini sesuai dengan apa yang dikemukakan oleh (Mudzakir \& Sutrisno, 1997) bahwa faktor-faktor yang memengaruhi prestasi belajar yaitu salah satunya adalah faktor internal berupa faktor fisiologis (yang bersifat fisik) dan faktor psikologis yang meliputi intelegensia, bakat dan minat yang dapat diasah melalui kegiatan ekstrakurikuler yang relevan dan bermanfaat, motivasi sebagai faktor dalam batin yang berfungsi menimbulkan, mendasari, dan mengarahkan perbuatan belajar, seta faktor kesehatan mental.

Selanjutnya dari hasil pengujian juga diperoleh sumbangan efektif variabel motivasi belajar siswa sebesar $25,6 \%$, dengan sumbangan relatif $52,4 \%$, sedangkan untuk variabel kegiatan ekstrakurikuler sanggar Alquran diperoleh sumbangan efektif sebesar 23,3\%, dengan sumbangan relatif sebesar $47,6 \%$. Hasil pengujian ini menunjukkan bahwa dalam penelitian ini variabel motivasi belajar siswa memberikan kontribusi yang relatif lebih besar atau memberikan pengaruh yang lebih dominan terhadap prestasi belajar siswa dibandingkan dengan kegiatan ekstrakurikuler sanggar Alquran. Hasil penelitian ini sejalan dengan penelitian Nuari (2015) yang menyimpulkan bahwa motivasi belajar memberikan kontribusi yang lebih besar terhadap prestasi belajar 
siswa dibandingkan dengan kontibusi kegiatan ekstrakurikuler terhadap ketercapain prestasi belajar.

\section{Kesimpulan}

Terdapat pengaruh yang signifikan motivasi belajar siswa terhadap prestasi belajar siswa Madrasah Aliyah di Kota Manado pada mata pelajaran Alquran Hadis. Hal ini berarti bahwa sebagian dari aspek prestasi belajar siswa dapat dijelaskan atau dipengaruhi oleh motivasi belajar siswa.

Terdapat pengaruh yang signfikan kegiatan ekstrakurikuler sanggar Alquran terhadap prestasi belajar siswa Madrasah Aliyah di Kota Manado pada mata pelajaran Alquran Hadis. Hal ini mengindikasikan bahwa sebagian dari aspek prestasi belajar siswa dapat dijelaskan atau dipengaruhi oleh kegiatan ekstrakurikuler.

Terdapat pengaruh yang signifikan motivasi belajar siswa dan kegiatan ekstrakurikuler sanggar Alquran secara bersama-sama terhadap prestasi belajar siswa Madrasah Aliyah di Kota Manado dalam mata pelajaran Alquran Hadis. Hal ini berarti bahwa sebagian dari aspek prestasi belajar siswa dapat dijelaskan atau dipengaruhi oleh motivasi belajar dan kegiatan ekstrakurikuler.

\section{Daftar Pustaka}

A.M., S. (2010). Interaksi dan Motivasi Belajar Mengajar. Jakarta: Rajawali Press.

Alfred, A. (2013). Perancangan Sanggar Batik di Yogyakarta. Yogyakarta: Universitas Kristen Duta Wacana.

Asy-Syarqawi, A. bin A. (2013). Tafsir Penutup Surat Albaqarah. Jakarta:

Islamhouse.com.

Bloom, B. S. (1989). Human Characteristics and School Learning. New York: McGrawHill Book Company.

Departemen Pendidikan Nasional. (2005). Kamus Besar Bahasa Indonesia (3rd ed.). Jakarta: Balai Pustaka.

Dimyati, \& Mujiono. (2002). Belajar dan Pembelajar. Jakarta: Depdikbud.

Gunawan, H. (2012). Kurikulum dan Pembelajaran Pendidikan Agama Islam. Bandung: PT. Alfabeta.

Gunawan, I., \& Palupi, A. R. (2012). Taksonomi Bloom - Revisi Ranah Kognitif: Kerangka Landasan untuk Pembelajaran, Pengajaran dan Penilaian. Jurnal Badan Penerbit IKIP PGRI Madiun, 2(2).

Handoko, M. (1992). Motivasi Daya Penggerak Tingkah Laku. Jakarta: PT. Rineka Cipta.

Harahap, Y. (2015). Pengaruh Motivasi Belajar dan Disiplin Belajar Terhadap Prestasi Belajar Alquran Hadis kelas X MAN Bijai. UIN Sumatera Utara.

Kompri. (2015). Motivasi Pembelajaran Perspektif Guru dan Siswa. Bandung: PT Remaja Rosdakarya.

Makmun, A. S. (1983). Psikologi Pendidikan. Bandung: Remaja Rosda Karya.

Martani, A. (2015). Keterkaitan Kegiatan Ekstrakurikuler Dengan Prestasi Belajar Siswa. Retrieved July 14, 2017, from http://eprints.ums.ac.id

Mas'ud, A. Q. (1998). Kamus Ilmiyah Populer. Surabaya: Bintang Pelajar.

McDonald, F. J. (1959). Educational Psychology. Tokyo: Overseas Publications, Ltd.

Mudzakir, A., \& Sutrisno, J. (1997). Psikologi Pendidikan. Bandung: Pustaka Setia.

Nashar. (2004). Peranan Motivasi dan Kemampuan Awal dalam Kegiatan Pembelajaran. 
Jakarta: Delia Press.

Nurkarima, R. (2012). Rima Nurkarima, Analisis Program Pembelajaran Tahsin dan Tahfidz Alquran dengan Metode Talaqqi di Kelas VII SMPIT Cordova Rancaekek Bandung. Universitas Islam Bandung.

Poerwadarminta, W. J. S. (2007). Kamus Umum Bahasa Indonesia. Jakarta: Balai Pustaka. Purwanto, N. (n.d.). Psikologi Pendidikan. Bandung: PT. Remaja Rosdakarya.

Ridwan, A. (2007). Tahsin, Tartil, dan Tahfidz. Bandung.

Singarimbun, \& Effendi. (2003). Metode Penelitian Survey. Jakarta: PT. Pustaka LP3ES Indonesia.

Sudjana. (2012). Metoda Stastika. Bandung: Tarsito.

Sugiyono. (2002). Metode Penelitian Pendidikan Pendekatan Kuantitatif, Kualitatatif dan $R \& D$. Bandung: Alfabeta.

Sukmadinata, N. S. (2005). Landasan Psikologi Proses Pendidikan. Jakarta: PT. Rosda Karya.

Uno, H. B. (2015). Teori Motivasi dan Pengukurannya. Bandung: Bumi Aksara.[] 